\title{
Quality and labelling of meat preparations on the Serbian market according to the new regulations
}

\author{
Jelena Budincevic ${ }^{1}$,Zoltan Szabo ${ }^{1}$, Nedjeljko Karabasil ${ }^{2}$, Mirjana Dimitrijevic ${ }^{2}$, Dragan Vasilev ${ }^{2}$
}

A b s t r a c t: The chemical quality parameters of meat preparations sampled from the domestic market were analysed from the aspect of regulations that define the quality of meat products and product labelling. A total of 30 meat preparations were investigated. They were classified in six groups as: minced meat with ingredients; ćevapčići; pljeskavica; barbecue meat; fresh sausages, and; fresh sausages under another name. The highest percentage of non-compliant meat preparations in terms of meat protein content and the content of collagen in meat protein was determined in fresh sausages (33\% were non-compliant). The highest percentage of the label non-compliances (60\%) concerned a missing nutritive declaration, but another serious problem was inadequate protein specification, as $54 \%$ of label errors concerned proteins; these errors included missing information about meat protein content, use of non-meat protein sources in meat preparations where these are banned, and inappropriate protein content designation. Other errors, including improper designation of the product group and additives, as well as missing information about the producer, occurred to a lesser extent.

Key words: meat products, quality, labelling, minced meat with ingredients, fresh sausages, protein content.

\section{Introduction}

Meat preparations are obtained from fresh meat and are intended for consumption after heat treatment, with the exception of steak tartare and carpaccio. During the production of meat preparations, addition of connective tissue, offal, processed meat, nitrites, nitrates, sulphur dioxide and sulphites is banned (Official Gazette RS, 2019). Allowed additives in meat preparations are defined by a special regulation concerning food additives (Official Gazette RS, 2018), and they can only be used in packed meat preparations in accordance with food labelling regulations (Official Gazette RS, 2017 and 2018). Meat preparations should be stored chilled between 0 and $4^{\circ} \mathrm{C}$, or frozen at least or below $-18^{\circ} \mathrm{C}$. Thawed meat preparations are not allowed to be frozen again (Official Gazette RS, 2019).

Meat preparations are produced and placed on the market according to the subdivision defined by the regulation (Serbia, 2019), as follows: 1) minced meat with ingredients (ćevapčići/ćevapi, pljeskavica, hamburger/burger); 2) barbecue meat; 3) fresh sausages; 4) marinated meat, and; 5) aged meat and steaks. Minced meat with ingredients is non-cured ground fresh meat and fatty tissue, containing only table salt and spices as ingredients, but when marketed as packaged food, it can contain additives in accordance with the special regulation on food additives. Barbecue meat is produced from ground fresh meat, fatty tissue and a wide range of ingredients which, besides table salt and spices, also includes sugars, water, fibre, starch, starch products, protein products, milk, milk products, eggs, egg products, oils, fats, other food of plant or animal origin, strong alcoholic drinks and natural aromas. Fresh sausages are meat preparations stuffed in natural (sheep small intestine) or artificial edible casings. Fresh sausages can be produced and marketed under the prescribed name "fresh sausage", which besides meat and fatty tissue, can contain table salt, spices, spice extracts, sugars, additives and water as ingredients, as well as "fresh sausage under another name", which is given by the producer; this latter product can contain all the same ingredients as fresh sausage, and all other ingredients as specified for barbecue meat. Marinated meat is a meat preparation obtained by marinating meat, bone-in or boneless, with its fatty and connective tissue. Aged meat and steaks are obtained by exposing meat to a ripening process, which includes the use of meat enzymes or added enzymes. 
Quality parameters for meat preparations are defined by regulation (Official Gazette RS, 2019), which determines raw materials, sensory properties and chemical parameters such as minimal content of meat protein (for minced meat with ingredients and fresh sausages) or total protein (barbecue meat). The meat or total protein content should be at least 14\%, the relative collagen content of meat protein or total protein should be at most $15 \%$, while in poultry meat preparations, relative collagen cannot exceed $10 \%$. Labelling of meat preparations is defined by local regulations (Official Gazette RS, 2017 and 2018), which are harmonized with European Union regulations (European Union, 2011). Some special labelling requirements concerning meat products are defined by the Regulation on the Quality of Minced Meat, Meat Preparations and Meat Products (Official Gazette RS, 2019).

The aim of this study was to investigate the chemical quality parameters and the label content accuracy of meat preparations, within the scope of this new local legislation.

\section{Materials and Methods}

The investigation was conducted on 30 meat products collected from the retail market: Minced meat with ingredients $(n=3)$; Ćevapčići $(n=3)$; Pljeskavica $(\mathrm{n}=8)$; Barbecue meat $(\mathrm{n}=7)$; Fresh sausage $(\mathrm{n}=3)$, and; Fresh sausage under another name $(\mathrm{n}=6)$. Each sample $(200 \mathrm{~g})$ was transported at $2 \pm 1^{\circ} \mathrm{C}$ to the laboratory and analysed during the 24 $\mathrm{h}$ after arrival.

Chemical quality parameters were investigated by standard methods as follows: protein content was analysed according to the reference method SRPS ISO 937:1992; collagen content was analysed according to the reference method SRPS ISO 3496:2002). The relative content of collagen in meat protein was calculated by the following formula:

$$
\begin{aligned}
& \text { Collagen content } \\
& \text { in protein }
\end{aligned}=\frac{\text { Collagen content }(\%) \times 100}{\text { Protein content }(\%)}
$$

The labels were investigated according the requirements of the Regulations on Food Declaration, Labeling and Advertising (Serbia, 2017 and 2018), so label information was collected on the product name, ingredient list, allergen info, additives, nett weight, expiration date, storage conditions, guide for use, data about the food business operator registered in the Republic of Serbia, country of origin, nutritive declaration, and series or lot number. According to the Regulation on the Quality of Minced Meat, Meat Preparations and Meat Products (Official Gazette, 2019), the name of the product group or subgroup, the meat protein content or total protein content and the collagen content in meat protein or in total protein must also be provided on the label. The proper use of additives was checked in accordance with the requirements of the Regulation for Food Additives (Official Gazette RS, 2018).

\section{Results and Discussion}

The results (Table 1) showed the highest average content of meat protein was found in ćevapčići $(16.29 \%)$ and the lowest in pljeskavica (14.16\%). However, concerning the individual meat preparations, the highest meat protein content was found in a sample of pljeskavica (18.87\%) and the lowest in a fresh sausage (10.94\%); this contained significantly below the minimum allowed meat protein content (14\%). Considering the total protein content, which includes the meat proteins and proteins from non-meat sources together (Official Gazette $R S, 2019)$, the average total protein was similar in fresh sausage under another name (16.01\%) and barbecue meat (15.85\%). Concerning the individual meat preparations, the highest total protein content $(19.25 \%)$ was found in a preparation of fresh sausage under another name.

The meat preparation group with the highest percentage of non-compliant samples, which did not meet the regulatory requirements of $14 \%$ meat protein or the total protein content (Official Gazette $R S, 2019)$, was fresh sausage (33\% were non-compliant). This is a named meat preparation prescribed by regulations and is expected to be a high quality product. Barbecue meat and fresh sausage under another name are generally considered as lower quality meat preparations, since non-meat protein and many other non-meat ingredients are allowed. In spite of the producers' ability to add protein, the total protein content was non-compliant for relatively high percentages of barbecue meat and fresh sausage under another name (14.3 and $16.6 \%$, respectively).

Meat proteins are highly digestible (about 95\%), which is significantly higher than the proteins in beans (78\%) and wheat (86\%) (Bhutta, 1999). From the nutritive and quality points of view, meat proteins are divided into muscle tissue protein and connective tissue protein (collagen). As collagen contains almost half the essential amino acids that muscle tissue protein contains, so it has half the nutritive value (Teodorovic et al., 2015). Therefore, the 
Table 1. Protein content in the grouped meat preparations

\begin{tabular}{lccccc}
\hline Meat preparation & $\overline{\mathbf{X}} \pm \mathbf{S D}$ & Minimum & Maximum & CV (\%) & Non-compliant* (\%) \\
\hline $\begin{array}{l}\text { Minced meat with } \\
\text { ingredients, MP }\end{array}$ & $16.06 \pm 0.66$ & 15.59 & 16.83 & 4.1 & - \\
Cevapcici, MP & $16.29 \pm 0.49$ & 15.76 & 16.74 & 3.0 & - \\
Pljeskavica, MP & $14.16 \pm 2.64$ & 14.10 & 18.87 & 18.6 & - \\
Barbecue meat, TP & $15.85 \pm 2.44$ & 12.18 & 17.61 & 15.3 & 14.3 \\
Fresh sausage, MP & $14.28 \pm 3.15$ & 10.94 & 17.81 & 22.11 & 33.3 \\
$\begin{array}{l}\text { Fresh sausage under } \\
\text { another name, TP }\end{array}$ & $16.01 \pm 2.08$ & 12.75 & 19.25 & 13.04 & 16.6 \\
\hline
\end{tabular}

$\overline{\mathrm{X}} \pm \mathrm{SD}$ - mean \pm standard deviation

$\mathrm{CV}$ - coefficient of variation

* Does not meet the regulatory requirements (Official Gazette RS, 2019)

MP — meat protein

$\mathrm{TP}$ - total protein

relative collagen content in protein (meat protein or total protein) content has been introduced as another important quality parameter, defined by regulation, and which must not be higher than $15 \%$. The collagen content in the meat preparations are shown in Table 2.

The results showed that the highest average content of collagen in meat protein (C/MP) was found in fresh sausage (13.87\%) and the lowest in ćevapčići and pljeskavica (9.88 and $9.98 \%$, respectively). However, concerning the individual samples, the highest content of collagen in meat protein was found in a fresh sausage $(16.33 \%)$ and the lowest in a sample of pljeskavica (6.71\%), while 33\% of fresh sausages did not meet the regulatory requirement that $\mathrm{C} / \mathrm{MP}$ must not be higher than $15 \%$. Considering the collagen content in total protein content, (C/TP) the highest $\mathrm{C} / \mathrm{TP}$ was determined in a barbecue meat (19.16). Altogether, $14.2 \%$ of all samples of this product did not meet this regulatory requirement, while all fresh sausages under another name complied with the regulation.

Meat preparations containing higher amounts of collagen have a lower nutritive value and worse sensory properties (Vukovic, 2012). This is usually a consequence of the presence of connective tissue contained in muscle fascicles (endomysium, perimysium, and epimysium) and tendons (Moon, 2006),

Table 2. Collagen content in protein in the grouped meat preparations

\begin{tabular}{lccccc}
\hline Meat preparation & $\overline{\mathbf{X}} \pm \mathbf{S D}$ & Minimum & Maximum & CV (\%) & Non-compliant* (\%) \\
\hline $\begin{array}{l}\text { Minced meat with } \\
\text { ingredients (C/MP) }\end{array}$ & $10.47 \pm 3.87$ & 6.75 & 14.48 & 36.98 & - \\
Cevapcici (C/MP) & $9.88 \pm 0.92$ & 8.96 & 10.80 & 9.31 & - \\
Pljeskavica (C/MP) & $9.98 \pm 2.58$ & 6.71 & 14.68 & 25.91 & - \\
Barbecue meat (C/TP) & $12.24 \pm 3.38$ & 9.00 & 19.16 & 27.64 & 14.2 \\
Fresh sausage (C/MP) & $13.87 \pm 2.51$ & 11.31 & 16.33 & 18.11 & 33.3 \\
Fresh sausage under & $10.18 \pm 2.67$ & 7.10 & 14.02 & 26.25 & - \\
another name (C/TP) & & & &
\end{tabular}

$\overline{\mathrm{X}} \pm \mathrm{SD}$ - mean \pm standard deviation

$\mathrm{CV}$ - coefficient of variation

* Does not meet the regulation requirements (Official Gazette RS, 2019)

$\mathrm{C} / \mathrm{MP}$ - collagen content in meat protein

$\mathrm{C} / \mathrm{TP}$ - collagen content in total protein 
Table 3. Number and percentage of non-compliant labels of the grouped meat preparations

\begin{tabular}{lccc}
\hline Meat preparation & Number of samples & Non-compliant (n) & Non-compliant* (\%) \\
\hline Minced meat with ingredients & 3 & 3 & 100 \\
Cevapcici & 3 & 2 & 66.7 \\
Pljeskavica & 8 & 6 & 75 \\
Barbecue meat & 7 & 5 & 71.4 \\
Fresh sausage & 3 & 3 & 100 \\
Fresh sausage under another name & 6 & 5 & 83.3 \\
\hline
\end{tabular}

* Does not meet the regulation requirements (Serbia, 2017 and 2018)

which should be thoroughly trimmed while preparing meat for the production of meat preparations. Connective tissue has a strong negative influence on sensory properties, making product tougher (Cross et al., 1973).

The results of the label content investigation showed there were issues concerning labelling that did not meet the regulatory requirements. The number of investigated and non-compliant meat preparation labels is shown in Table 3.

The results show that every group of investigated meat preparations had some error in the labels, and the percentage of non-compliant labels was very high over all groups (from 66.7 to $100 \%$ ). For minced meat with ingredients and fresh sausage, the labels of every product studied contained error(s). According to the literature, some investigations in the European Union show deviations in food labels of up to $50 \%$ from the legal requirements, mostly including smaller mismatches, but sometimes bigger or even fraudulent cases are dealt with (Arayess \& Hendrickx, 2016).
The main reasons for the label non-compliances are presented in Table 4, and we note 30 of the investigated meat preparations had more than one labelling error.

The highest percentage of the label non-compliances $(60 \%)$ concerned a missing nutritive declaration, but inadequate specification of proteins was also an extremely serious problem, since $54 \%$ of label errors referred to proteins, such as missing information about meat protein content (20\%), use of non-meat protein sources in preparations where this is not allowed (17\%) and inappropriate protein content designation $(17 \%)$. Other errors occurred to a lesser extent, and included improper designation of the product group and additives, as well as missing information about the producer.

Proper labelling is of great importance, giving information to consumers about the composition and main properties of food, and must not be misleading or confusing. As food labelling is a complex requirement, the general demands are regulated by law (Henderikx, 2017). Serbian regulations

Table 4. Main reasons for label non-compliance in meat preparations $(n=30)$

\begin{tabular}{lcc}
\hline Label error & N* & (\%) \\
\hline Missing nutritive declaration & 18 & 60 \\
Missing information about meat protein content & 6 & 20 \\
Use of non-meat protein sources where it is not allowed & 5 & 17 \\
Inappropriate protein content designation & 5 & 17 \\
Inappropriate product group & 5 & 17 \\
Inappropriate name or designation of additives & 2 & 7 \\
Use of additives which are not allowed & 2 & 7 \\
Missing data about food business operator & 2 & 7 \\
\hline
\end{tabular}

$* \mathrm{~N}$ - number of meat preparation labels that contained the error 
concerning labelling (Official Gazette RS, 2017 and 2018) are harmonized with the European Union regulations (European Union, 2011), and an obligatory nutritive declaration as a part of the label was recently introduced. This could be considered as the main reason that missing nutritive declarations were the most frequent label error. Among meat preparations, ćevapčići and pljeskavica, because of their sensory properties, are especially appreciated by consumers. This opens some possibilities for fraud by unallowed use of non-meat protein sources in these products. In order to overcome these issues, such problems should be appropriately addressed by the food business operators and the competent authorities. However, consumers also need to be informed, so they can understand the information stated on the labels (Henderikx, 2017).

\section{Conclusion}

The highest meat protein content was found in a sample of pljeskavica $(18.87 \%)$ and the lowest in a fresh sausage (10.94\%). The group of meat products with highest percentage of non-compliant samples was the group of fresh sausages (33\%). For barbecue meat and fresh sausage under another name, the total protein content was non-compliant for a relatively high percentage of each group (14.3 and 16.6\%, respectively). The highest content of collagen in meat protein was determined in a fresh sausage $(16.33 \%)$ and the lowest in a sample of pljeskavica $(6.71 \%)$, while $33 \%$ of fresh sausages did not meet the regulatory requirements for collagen. The highest collagen content in total protein content was determined in a sample of barbecue meat $(19.16 \%$ of collagen in protein), while $14.2 \%$ of all samples of this product did not meet the regulatory requirement. Every group of investigated meat preparations had some labelling error(s), and the percentage of non-compliant labels was very high among the different groups of meat preparations (from 66.7 to $100 \%$ ). The highest percentage of the label non-compliances $(60 \%)$ concerned a missing nutritive declaration, but inadequate specification of proteins is also a serious problem, since $54 \%$ of label errors concerned protein declarations. These errors included missing information about meat protein content, use of non-meat protein sources in preparations where this is not allowed and inappropriate protein content designation. Other errors occurred to a lesser extent and included improper designation of the product group and additives, as well as missing information about the producer.

\title{
Kvalitet i deklarisanje poluproizvoda od mesa na tržištu Srbije u skladu sa novim propisima
}

\author{
Jelena Budinčević, Zoltan Sabo, Nedjeljko Karabasil, Mirjana Dimitrijević, Dragan Vasilev
}

A p s t r a k t: U radu su prikazani rezultati ispitivanja hemijskih parametara kvaliteta poluproizvoda od mesa uzorkovanih na domaćem tržištu, koji su analizirani sa aspekta propisa koji definišu kvalitet proizvoda od mesa i deklarisanje hrane. Ukupno je ispitano 30 uzoraka poluproizvoda od mesa uključujući Usitnjeno meso sa dodacima, Ćevapčiće, Pljeskavice, Roštilj meso, Svežu kobasicu i sveže kobasice pod drugim nazivom. Najveći procenat uzoraka koji nisu ispunjavali odredbe u pogledu sadržaja proteina mesa i udela kolagena u proteinima mesa utvrđen je kod Sveže kobasice (33\%). Najveći procenat neusaglašenosti deklaracija (60\%) bio je nedostatak nutritivne deklaracije, ali veliki problem predstavlja i neadekvatno navođenje proteina (54\%) u smislu ne navođenja sadržaja proteina, upotrebe proteina koji ne potiču od mesa tamo gde to nije dozvoljeno i neadekvatno navođenje sadržaja proteina. Ostali nedostaci se odnose na neadekvatno navođenje pripadnosti grupi i aditiva, kao i nedostatak podataka o proizvođaču.

Ključne reči: poluproizvodi od mesa, kvalitet, deklarisanje.

Disclosure Statement: No potential conflict of interest was reported by the authors. 


\section{References}

Arayess, S. \& Hendrickx J. (2016). Misleiding op verpakkingen (Deception on packagings).VMT, Voedingsmiddelen, management en technologie, 8, 34-36.

Bhutta Z. (1999). Protein: Digestibility and availability. In: Encyclopedia of Human Nutrition. Eds. M. Sadler, J. Strain \& B. Caballero. San Diego: Academic Press, 1646-1656.

Cross, H. R., Carpenter, Z. I . \& Smith G. C. (1973). Effect of intramuscular collagen and elastin on bovine muscle tenderness. Journal of Food Science, 38, 998-1004.

European Union. (2011). Regulation (EU) No 1169/2011 of the European Parliament and of the Council of 25 October 2011 on the provision of food information to consumers, amending Regulations (EC) No1924/2006 and (EC) No 1925/2006 of the European Parliament and of the Council, and repealing Commission Directive 87/250/EEC, Council; Directive 90/496/EEC, Commission Directive 1999/10/EC, Directive 2000/13/EC of the European Parliament and of the Council, Commission Directives 2002/67/EC and 2008/5/EC and Commission Regulation (EC) No 608/2004.
Henderikx, F. (2017). Labelling of food: a challenge for many. Veterinarski Glasnik, 71(1), 16-23.

Moon, S. S. (2006). The Effect of quality grade and muscle on collagen contents and tenderness of intramuscular connective tissue and myofibrillar protein for Hanwoo beef. Asian-Aust. Journal of Animal Science, 19(7), 1059-1064.

Official Gazette of the Republic of Serbia 19/2017 and 16/2018. Regulation on declaration, labeling and food advertising.

Official Gazette of the Republic of Serbia 50/2019. Regulation on the quality of minced meat, meat preparations and meat products.

Official Gazette of the Republic of Serbia 53/2018. Regulation on the food additives.

Teodorovic V., Karabasil N., Dimitrijević M. \& Vasilev D. (2015). Higijena i tehnologija mesa, Naučna, Beograd

Vukovic I. (2012). Osnove tehnologije mesa, treće izdanje, VKS, Beograd.

Paper received: 13.12.2019.

Paper corrected: 16.12.2019.

Paper accepted: 16.12.2019. 